\title{
Czy Kazimierz Dolny jest pomnikiem historii?
}

\section{Anna Wieczorek}

\section{STRESZCZENIE}

Pozostaje bezspornym, że Kazimierz Dolny ma szczególne wartości dla kultury, a tym samym spełnia wymagania stawiane obiektowi, który chce się uznać za pomnik historii. Niestety, regulacje dotyczące ochrony zabytków: decyzje z 1966 r. i z 1983 r. o wpisie do rejestru zabytków oraz zarządzenie Prezydenta RP z 1994 r. w sprawie uznania za pomnik historii Kazimierza Dolnego budzą szereg wątpliwości natury merytorycznej i prawnej - nie wiadomo czy obowiązują. Taka sytuacja wywołuje konflikty pomiędzy mieszkańcem Kazimierza Dolnego a władzami, w szczególności wojewódzkim konserwatorem zabytków.

Dla zapewnienia Kazimierzowi Dolnemu odpowiedniej ochrony konserwatorskiej należy doprowadzić do wyeliminowania z obrotu prawnego ww. decyzji z 1966 r. i z 1983 r. oraz zarządzenia z 1994 r. Następnie powinno zostać wydane rozporządzenie Prezydenta RP w sprawie uznania za pomnik historii, które w sposób jednoznaczny określi przedmiot i zasady ochrony. Wydanie rozporządzenia trzeba poprzedzić badaniami, które w sposób jednoznaczny wskażą obszar podlegający ochronie oraz co i dlaczego na tym obszarze należy chronić.

Artykuł należy traktować jako apel o likwidację chaosu prawnego dotyczącego zabytków. W podobnej sytuacji jak Kazimierz Dolny jest kilkanaście obiektów, które uznano za pomniki historii zarządzeniami Prezydenta RP wydanymi w 1994 r. Ochrona zabytków jest obowiązkiem zarówno władz, jak i społeczeństwa. Żeby była skuteczna, nie może być nacechowana uznaniowością. Tylko jednoznacznie, precyzyjnie ustalone obowiązki znajdą akceptacje społeczną, a bez niej trudno coś chronić.

Ponadto potrzebna jest szeroko rozumiana edukacja. Karami nie wymusi się wrażliwości na piękno i szacunku dla historii. Uznanie za pomnik historii powinno być traktowane jako zaszczyt przez mieszkańców terenu, który ten status uzyskał, a nie jako „dopust boży”.

Słowa kluczowe: Kazimierz Dolny, zabytki, rejestr zabytków, pomnik historii

\section{Wprowadzenie}

Na stronie internetowej pt. „Kazimierz Dolny - Oficjalna Strona Miasta Kazimierz Dolny” [si.OSMKD] umieszczono informuję, że „Kazimierz Dolny jest jednym z 54 wyjątkowych miejsc w Polsce - posiadających status Pomnika Historii. Uznania Kazimierza Dolnego za pomnik historii dokonał Prezydent Rzeczypospolitej Polskiej Lech Wałęsa Zarządzeniem nr 417 z dnia 8 września 1994 r. (Monitor Polski nr 50)."

Poniżej przytoczono w całości treść ww. zarządzenia i załącznik graficzny (ryc. 1). 


\section{Zarządzenie Prezydenta Rzeczypospolitej Polskiej w sprawie uznania za pomnik historii} z dnia 8 września 1994 r. (M.P. nr 50, poz. 417)

„Na podstawie art. 6 ust. 1 ustawy z dnia 15 lutego 1962 r. o ochronie dóbr kultury i o muzeach (Dz.U. nr 10, poz. 48, z 1983 r. nr 38, poz. 173, z 1989 r. nr 35, poz. 192 oraz z 1990 r. nr 34, poz. 198 i nr 56, poz. 322) zarządza się, co następuje:

$\S 1$

Uznaje się za pomnik historii „Kazimierz Dolny”, położony w województwie lubelskim. $\S 2$

Celem ochrony pomnika historii wymienionego w $\S 1$ jest zachowanie, ze względu na wyjątkowe, uniwersalne wartości oraz autentyczność i integralność, układu urbanistycznego, zabudowy mieszkalnej i pełnego programu budowli monumentalnych z okresu staropolskiego.

\section{$\S 3$}

1. Granica zespołu zabytkowego obejmuje: Kazimierz Dolny wraz z Męćmierzem, Albrechtówką Za Dębem, Lasem Miejskim i Jeziorszczyzną i przebiega zgodnie z granicą ochrony konserwatorskiej wyznaczoną na miejscowym planie ogólnym zagospodarowania przestrzennego Kazimierza Dolnego, zatwierdzonym dnia 28 lutego 1989 r. uchwałą Rady Narodowej Miasta i Gminy Kazimierz Dolny z dnia 28 lutego 1989 r.

2. Mapa „Kazimierza Dolnego” stanowi załącznik do zarządzenia.

\section{$\S 4$}

Zarządzenie wchodzi w życie z dniem ogłoszenia."

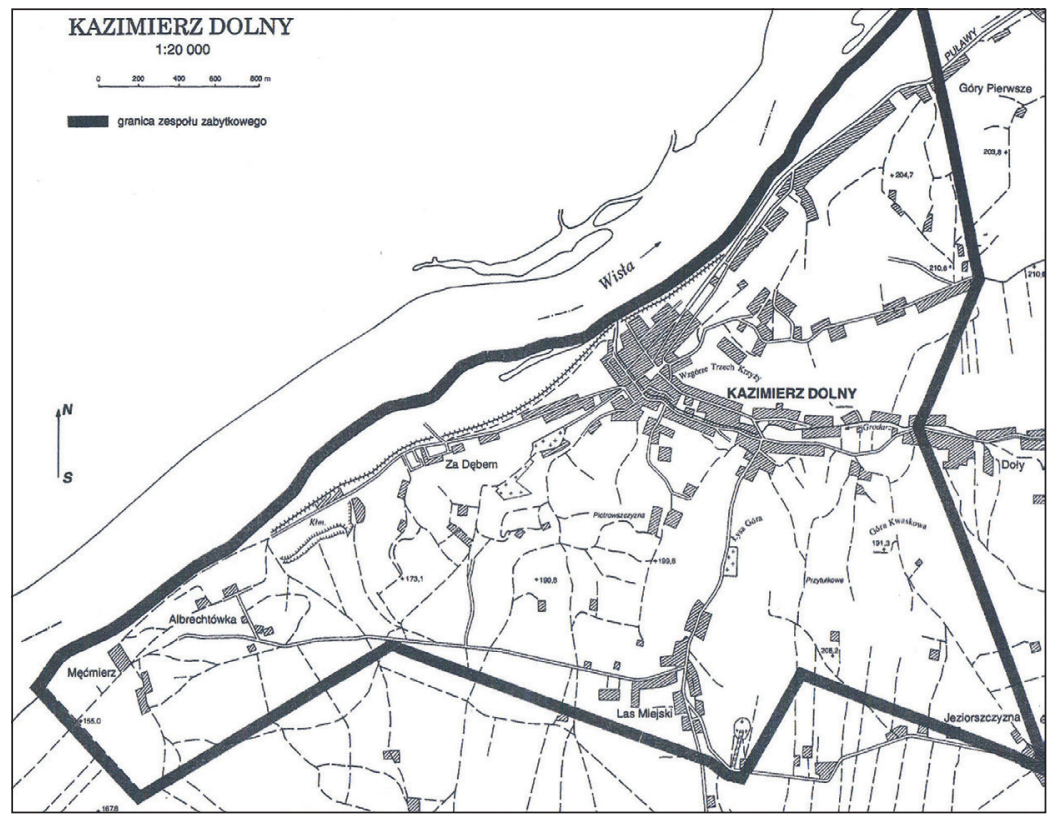

Ryc. 1. Załącznik do Zarządzenia Prezydenta Rzeczypospolitej Polskiej z dnia 8 września 1994 r. 
Kazimierza Dolnego nie trzeba przedstawiać. Jest to miejsce powszechnie znane ze swoich zabytków, przełomu Wisły, malowniczych wzgórz i wąwozów porośniętych piękną roślinnością. Nazwa miasta wynika z jego położenia - Dolny, ponieważ jest położony w dole Wisły w stosunku do Kazimierza, stanowiącego dzielnicę Krakowa [si.OSMKD].

„Gmina Kazimierz Dolny jest gminą miejsko-wiejską, położoną (...) w powiecie puławskim. W skład gminy wchodzi miasto Kazimierz Dolny oraz 14 sołectw: Bochotnica, Cholewianka, Dąbrówka, Doły-Wylągi, Góry, Jeziorszczyzna, Mięćmierz-Okale, Parchatka, Rzeczyca, Rzeczyca-Kolonia, Skowieszynek, Wierzchoniów, Witoszyn, Zbędowice." [si.OSMKD].

„Powierzchnia gminy obejmuje obszar $72,49 \mathrm{~km}^{2}$, z czego miasto zajmuje 30,42 km², natomiast tereny wiejskie $42,04 \mathrm{~km}^{2}$. Gmina zlokalizowana jest na zachodnim skraju Wyżyny Lubelskiej, w obrębie Płaskowyżu Nałęczowskiego, w Małopolskim Przełomie Wisły, na prawym jej brzegu. (...) Od Puław miasto Kazimierz Dolny oddalone jest o 14 km, zaś od Lublina - stolicy województwa - dzieli je 56 km." [si.OSMKD]. W grudniu 2019 r. Kazimierz Dolny liczył 2530 mieszkańców [si. GUS].

Można przyjąć, że „historia miasta zaczyna się od czasu, kiedy posiadłości, w których obrębie powstać miał kiedyś Kazimierz (...) darowane zostały przez Kazimierza Sprawiedliwego około r. 1181 klasztorowi Premonstratensów, czyli norbertanów obojga płci na Zwierzyńcu pod Krakowem” [Adamczyk-Grabowska, s. 63]. Posiadłości te „Kazimierz Wielki, oceniwszy snadź ich znaczenie dla państwa, wziął (...) w posiadanie, częściowo drogą wymiany z klasztorem zwierzynieckim” [Adamczyk-Grabowska 2010, s. 64]. „Przywileje w archiwum miejskim zachowane sięgają czasów króla Władysława Jagiełły. Najdawniejszy z nich pochodzi z r. 1406" [Adamczyk-Grabowska 2010, s. 51].

„Kazimierz Dolny jest miasteczkiem o bogatych tradycjach kulturalnych. Kultura nie tylko w dużej mierze nadała mu obecny kształt, jest ona też motorem napędzającym jego życie i rozwój oraz istotnym czynnikiem budującym tożsamość miasta. Kazimierz jest powszechnie kojarzony jako ośrodek artystyczny, miejsce festiwali, licznych imprez kulturalnych, dziesiątków galerii, plenerów." [si.OSMKD].

Wydaje się, że to zaszczyt być mieszkańcem miasta o statusie pomnika historii. Trzeba jednak pamiętać, iż wiążą się z tym obowiązki i kłopoty. Warto wiedzieć, czym są zabytki i pomniki historii oraz jakie to wywołuje skutki prawne.

\section{Zabytki i ich ochrona}

\section{Zabytki - definicje}

W rozumieniu ustawy o ochronie zabytków i opiece nad zabytkami (uoz) zabytek to „nieruchomość lub rzecz ruchoma, ich części lub zespoły, będące dziełem człowieka lub związane z jego działalnością i stanowiące świadectwo minionej epoki bądź zdarzenia, których zachowanie leży w interesie społecznym ze względu na posiadaną wartość historyczna, artystyczną lub naukową" [art. 3 pkt 1 uoz]. 
Powyższa ustawa wyróżnia trzy podstawowe rodzaje zabytków:

1. zabytki nieruchome, czyli nieruchomości, ich części lub zespoły, np.: układ urbanistyczny i zespoły budowlane, dzieła architektury i budownictwa, obiekty obronne, obiekty techniki (kopalnie, huty, elektrownie), cmentarze, parki i inne formy zaprojektowanej zieleni [art. 3 pkt 2 i art. 6 ust. 1 pkt 1 uoz];

2. zabytki ruchome, np.: dzieła sztuk plastycznych i rzemiosła artystycznego, numizmaty, militaria, wytwory techniki, materiały biblioteczne [art. 3 pkt 3 i art. 6 ust. 1 pkt 1 uoz];

3. zabytki archeologiczne [art. 3 pkt 4 uoz].

\section{Formy ochrony zabytków i ewidencja zabytków}

Ustawa o ochronie zabytków i opiece nad zabytkami ustanawia następujące formy ochrony zabytków:

1. „wpis do rejestru zabytków” [art. 7 pkt 1 uoz];

2. „wpis na Listę Skarbów Dziedzictwa” [art. 7 pkt 1a uoz];

3. „uznanie za pomnik historii” [art. 7 pkt 2 uoz];

4. „utworzenie parku kulturowego" [art. 7 pkt 3 uoz];

5. „ustalenia ochrony w miejscowym planie zagospodarowania przestrzennego albo w decyzji o ustaleniu lokalizacji inwestycji celu publicznego, decyzji o warunkach zabudowy, decyzji o zezwoleniu na realizację inwestycji drogowej, decyzji o ustaleniu lokalizacji linii kolejowej lub decyzji o zezwoleniu na realizację inwestycji w zakresie lotniska użytku publicznego" [art. 7 pkt 4 uoz].

Do rejestru zabytków wpisuje się zabytki nieruchome na podstawie decyzji, którą wydaje wojewódzki konserwator zabytków, na wniosek właściciela obiektu albo z urzędu [art. 9 ust. $1 \mathrm{uoz}$ ].

Listę Skarbów Dziedzictwa prowadzi minister właściwy do spraw kultury i ochrony dziedzictwa narodowego. Wpisuje się na nią zabytki ruchome o szczególnej wartości [art. 14 a ust. 1 i ust 2 uoz].

Wyjątkowo cenne zabytki nieruchome mogą uzyskać status pomnika historii. „Prezydent Rzeczypospolitej Polskiej, na wniosek ministra właściwego do spraw kultury i ochrony dziedzictwa narodowego, w drodze rozporządzenia, może uznać za pomnik historii zabytek nieruchomy wpisany do rejestru lub park kulturowy o szczególnej wartości dla kultury, określając jego granice." [art. 15 ust. 1 uoz].

„Minister właściwy do spraw kultury i ochrony dziedzictwa narodowego może przedstawić Komitetowi Dziedzictwa Światowego wniosek o wpis pomnika historii na „Listę dziedzictwa światowego" w celu objęcia tego pomnika ochroną na podstawie Konwencji w sprawie ochrony światowego dziedzictwa kulturalnego i naturalnego, przyjętej w Paryżu dnia 16 listopada 1972 r." [art. 15 ust. 4 uoz]. 
Park kulturowy powstaje w celu ochrony krajobrazu kulturowego, na podstawie uchwały rady gminy, pozytywnie zaopiniowanej przez wojewódzkiego konserwatora zabytków [art. 16 ust. $1 \mathrm{uoz}$ ].

Ochronę danego obiektu czy obszaru wprowadza:

1. w miejscowym planie zagospodarowania przestrzennego rada gminy stosowną uchwała; 2. w ww. decyzjach o ustaleniu lokalizacji organy, który te decyzje wydają.

Ustawa o ochronie zabytków i opiece nad zabytkami, prócz form ochrony zabytków, wprowadza dodatkowe pojęcie - ewidencja zabytków. Ewidencja zabytków nie jest formą ochrony zabytków, ale zbiorem danych, które służą np. do sporządzania programów opieki nad zabytkami [art. $21 \mathrm{uoz}$ ]. Nie wszystkie obiekty wymienione w ewidencji zabytków są objęte formami ochrony zabytków.

Krajową ewidencję zabytków prowadzi Generalny Konserwator Zabytków, wojewódzką - wojewódzki konserwator zabytków, a gminną - wójt, burmistrz lub prezydent miasta [art. 22 ust. 1, ust. 2 i ust. 4 uoz].

\section{Uprawnienia wojewódzkiego konserwatora zabytków}

Wojewódzki konserwator zabytków ma bardzo szeroki zakres uprawnień. Na obszarach wpisanych do rejestru zabytków decyduje o podstawowych dziedzinach życia mieszkańców.

„Pozwolenia wojewódzkiego konserwatora zabytków wymaga:

1. prowadzenie prac konserwatorskich, restauratorskich lub robót budowlanych przy zabytku wpisanym do rejestru, w tym prac polegających na usunięciu drzewa lub krzewu z nieruchomości lub jej części będącej wpisanym do rejestru parkiem, ogrodem lub inną formą zaprojektowanej zieleni;

2. wykonywanie robót budowlanych w otoczeniu zabytku;

3. prowadzenie badań konserwatorskich zabytku wpisanego do rejestru;

4. prowadzenie badań architektonicznych zabytku wpisanego do rejestru;

5. prowadzenie badań archeologicznych;

6. przemieszczanie zabytku nieruchomego wpisanego do rejestru;

7. trwałe przeniesienie zabytku ruchomego wpisanego do rejestru, z naruszeniem ustalonego tradycją wystroju wnętrza, w którym zabytek ten się znajduje;

8. dokonywanie podziału zabytku nieruchomego wpisanego do rejestru;

9. zmiana przeznaczenia zabytku wpisanego do rejestru lub sposobu korzystania z tego zabytku;

10. umieszczanie na zabytku wpisanym do rejestru: urządzeń technicznych, tablic reklamowych lub urządzeń reklamowych (...) oraz napisów (...);

11. podejmowanie innych działań, które mogłyby prowadzić do naruszenia substancji lub zmiany wyglądu zabytku wpisanego do rejestru, z wyłączeniem działań polegających 
na usuwaniu drzew lub krzewów z terenu nieruchomości lub jej części niebędącej wpisanym do rejestru parkiem, ogrodem albo inną formą zaprojektowanej zieleni;

12. poszukiwanie ukrytych lub porzuconych zabytków ruchomych, w tym zabytków archeologicznych, przy użyciu wszelkiego rodzaju urządzeń elektronicznych i technicznych oraz sprzętu do nurkowania." [art. 36 ust. 1 pkt od 1 do 12 uoz].

Ponadto wojewódzki konserwator zabytków uzgadnia projekty planów zagospodarowania przestrzennego województw oraz miejscowych planów zagospodarowania przestrzennego - teoretycznie tylko „w zakresie kształtowania zabudowy zagospodarowania terenu” [art. $20 \mathrm{uoz}]$, ale w praktyce konserwatorzy decydują o wszystkim, np. o przeznaczeniu terenów.

\section{Kary}

Kto bez pozwolenia wojewódzkiego konserwatora zabytków lub niezgodnie z zakresem i warunkami określonymi w pozwoleniu, podejmuje działania takie jak:

1. roboty budowlany przy zabytku wpisanym do rejestru lub w jego otoczeniu;

2. usunięcie drzewa lub krzewu z nieruchomości będącej wpisanym do rejestru parkiem, ogrodem lub inną formą zaprojektowanej zieleni;

3. prowadzenie badań konserwatorskich i architektonicznych zabytku wpisanego do rejestru;

4. prowadzenie badań archeologicznych - podlega karze pieniężnej w wysokości od 500 zł do 500000 zł [art. 107d ust. 1 i ust 2]. Niszczenie zabytków lub uszkadzanie zabytków „podlega karze pozbawienia wolności od 6 miesięcy do lat 8." [art. 108 ust. 1 uoz].

\section{Obowiązki i prawa właściciela zabytku}

Osoba, posiadająca tytuł prawny do zabytku, finansuje prowadzenie prac konserwatorskich, restauratorskich i robót budowlanych przy tym zabytku [art. 71 ust. 1 i ust. 2 uoz].

Właściciel lub posiadacz zabytku wpisanego do rejestru albo na Listę Skarbów Dziedzictwa, może ubiegać się o udzielenie dotacji z budżetu państwa na dofinansowanie prac konserwatorskich, restauratorskich lub robót budowlanych [art. 73 uoz]. Dotacja może być udzielona w wysokości do 50\% koniecznych nakładów [art. 78 ust. 1], a jeżeli zabytek ma wyjątkową wartość nawet do $100 \%$ [art. 78 ust. 2 uoz].

\section{„Wyrok w sprawie PSEUDO-wpisu Kazimierza Dolnego do rejestru zabytków”}

Na stronie internetowej pt. „Z rynku” podtytuł „Strona internetowa Mieszkańców Kazimierza Dolnego" [http://z - rynku.pl 2020/03] ukazał się artykuł Krzysztofa Wawra pt. Wyrok w sprawie PSEUDO-wpisu Kazimierza Dolnego do rejestru zabytków, z którego dowiadujemy się, że istnieją dwie decyzje wpisujące Kazimierz Dolny do rejestru zabytków. Decyzje wydano 
w 1966 r. oraz w 1983 r. Decyzje te odmiennie określają obszar i obiekty podlegające ochronie. Mieszkaniec Kazimierza Dolnego zaskarżył decyzję z 1983 r. Minister Kultury i Dziedzictwa Narodowego decyzją z dnia 17 czerwca 2019 r. odmówił stwierdzenia nieważności ww. decyzji z 1983 r. Wojewódzki Sąd Administracyjny (WSA) wyrokiem z dnia 13 lutego 2020 r. sygn. akt VII SA/Wa 1960/19:

1. uchylił decyzję z dnia 17 czerwca 2019 r. Ministra Kultury i Dziedzictwa Narodowego;

2. nie uchylił wprawdzie decyzji z 1983 r., ale uznał, że ww. decyzja wprowadza stan niepewności prawnej, bo nie wiadomo jaki obszar Kazimierza Dolnego podlega ochronie;

3. zobligował Ministra Kultury i Dziedzictwa Narodowego do wydania rozstrzygnięcia zgodnego z oceną prawną, dokonaną przez WSA.

W opinii Sądu „decyzja WKZ z 1983 r. wywołała skutki, niemożliwe do zaakceptowania w państwie prawa, przez wprowadzenie stanu niepewności prawnej co do tego, jaki w rzeczywistości obszar Kazimierza Dolnego podlega ochronie konserwatorskiej i na jakiej podstawie. W obrocie prawnym funkcjonują bowiem dwie decyzje, odmiennie określające przedmiot ochrony konserwatorskiej zabytku - Kazimierza Dolnego. Jak już była o tym mowa, nie można przez porównanie sentencji obu decyzji (z 1966 r. i z 1983 r.) ustalić, jak poszerzony został obszar chroniony" [Wawer 2020].

Do procesu doszło, ponieważ w 2017 r. Lubelski Wojewódzki Konserwator Zabytków zawiadomił Prokuraturę Rejonową w Puławach o przestępstwie polegającym na wycince drzew, popełnionym przez mieszkańca Kazimierza Dolnego. Oskarżony postanowił się bronić i skierował sprawę do sądu [Wawer 2020].

Artykuł K. Wawra wskazuje na brak jednoznacznych regulacji dotyczących ochrony zabytków, co prowadzi do konfliktów pomiędzy mieszkańcami Kazimierza Dolnego a wojewódzkim konserwatorem zabytków.

Taki stan rzeczy potwierdza Pan Janusz Kowalski, radny miasta i gminy Kazimierz Dolny, w wywiadzie przeprowadzonym w dniu 16.03.2020 r., telefonicznie i za pomocą poczty elektronicznej, na potrzeby niniejszego artykułu [załącznik 1]. Radny podkreśla, „że nikt nie potrafi wskazać precyzyjnego przebiegu granicy strefy ochrony konserwatorskiej. Ta została wrysowana, na załączniku graficznym do Zarządzenia Prezydenta RP, od linijki na mapie w skali 1:20 000. Grubość linii ma kilka milimetrów, co w terenie oznacza szerokość kilkudziesięciu metrów. Mieliśmy już do czynienia z kuriozalnymi interpretacjami Lubelskiego Wojewódzkiego Konserwatora Zabytków, iż granica biegnie po brzegu linii - a dlaczego nie w jej osi, co wprost wynika z kartografii? Przebieg granicy pociąga za sobą szereg implikacji, bowiem w strefie ochrony konserwatorskiej właściwy konserwator uzgadnia projekty miejscowych planów zagospodarowania przestrzennego, zezwala na wycinkę drzew, uzgadnia projekty budowlane itp." [załącznik 1].

Artykuł K. Wawra oraz wywiad z radnym miasta i gminy Kazimierz Dolny pokazuja, że pozornie mało znaczący proces, którego praprzyczyną była wycinka drzew, może stać się przysłowiową kulą śnieżna, która uruchomi „lawinę” spraw dotyczących wpisów do rejestru zabytków i pomników historii. 


\section{Kazimierz Dolny - ustanowienie pomnika historii}

\section{Decyzja z 13 sierpnia 1966 r. w sprawie wpisania dobra kultury do rejestru zabytków}

Decyzję z 13 sierpnia 1966 r. w sprawie wpisania dobra kultury do rejestru zabytków, nr KZ.V-7/55/66, nr rejestru Dział A/46:

1. wydano na podstawie art. $4 \mathrm{i}$ art. 14 ust. 1 ustawy z dnia 15 lutego 1962 r. o ochronie dóbr kultury i o muzeach (Dz.U. nr 10, poz. 48) oraz art. 99 Kodeksu postępowania administracyjnego;

2. podpisał ją Główny Konserwator Zabytków Województwa Lubelskiego.

W decyzji z 1966 r. napisano:

„Wpisuje się do rejestru zabytków województwa obszar miasta Kazimierza Dolnego ze wszystkimi budynkami murowanymi i drewnianymi, ruinami, drzewostanem, ulicami, drogami i wąwozami, według granicy biegnącej wybrzeżem Wisły, a następnie do punktu 1, sto metrów za ostatnim spichrzem, licząc od Rynku, na drodze puławskiej nad Wisłą w górę prostopadle do tej drogi do punktu 2 na skrzyżowaniu z drogą na drugich górach go Bochotnicy, dalej do punktu 3 na drodze Wylęgowskiej przy rozejściu się dróg, przez punkty 4, 5 do 6 po prostej od zejścia się dróg z Cholewianki, Mięcimierza i szosy Opolskiej, stamtąd do punktu 7 po drodze pod lasem miejskim do rozwidlenia dróg na Mięcimierz i do przewozu, wreszcie do punktu 6 nad Wisła, po drodze między Mięcimierzem i Skałą, zgodnie z załączoną mapą."

„UZASADNIENIE: jako wybitnie cenny kompleks budynków zabytkowych i ruin, typowe ukształtowanie terenowe $\mathrm{z}$ bogatym drzewostanem stanowiące charakterystyczne i malownicze zespolenie architektury z krajobrazem."

Do decyzji dołączona jest mapa w skali $1: 25000$ (ryc. 2).

Decyzja nie ustala, na czym ma polegać ochrona obiektów w niej wymienionych. Granice obszaru podlegającego ochronie są wyznaczone mało precyzyjnie. Określa je:

1. nieprecyzyjny opis (np. „sto metrów za ostatnim spichrzem, licząc od Rynku”- który ze spichrzy jest ostatni i od którego punktu rynku należy liczyć - nie wiadomo);

2. nieprecyzyjna mapa, której nie da się dopasować do stosowanych obecnie map, pochodzących z państwowego zasobu geodezyjnego i kartograficznego; zła jakość techniczna jest dodatkowym powodem braku precyzji - mapa ma ponad 50 lat.

\section{Decyzja z 24 stycznia 1983 r. w sprawie wznowienia wpisu dobra kultury do rejestru zabytków}

Decyzję z 24 stycznia 1983 r. w sprawie wznowienia wpisu dobra kultury do rejestru zabytków, nr KL.IV-5349/1/83, dział A/46:

1. wydano na podstawie art. 4 i art. 14 ust. 1 ustawy z dnia 15 lutego 1962 r. o ochronie dóbr kultury i o muzeach (Dz.U. nr 10, poz. 48) oraz art. 104 Kodeksu postępowania administracyjnego; 
2. podpisał ją Wojewódzki Konserwator Zabytków.

W decyzji z 1983 r. napisano:

1. „wznawia się decyzję nr KL.V-7/59/66 z dnia 13 sierpnia 1966 r. w sprawie wpisania do rejestru zabytków województwa lubelskiego pod pozycją A/46 obszaru miasta Kazimierza Dolnego";

2. „decyzją obejmuje się zespół urbanistyczno-architektoniczno-krajobrazowy miasta Kazimierza Dolnego wraz ze wszystkimi placami, ulicami, drogami, budynkami murowanymi i drewnianymi, ruinami, wąwozami i drzewostanem w granicach określonych na załączonym planie linią łączącą punkty ABCDEFGHIA " - (ryc. 3).

Wojewódzki Sąd Administracyjny trafnie zauważył, że decyzja z 1983 r. wprowadza stan niepewności prawnej - nie określa jednoznacznie, jaki obszar Kazimierza Dolnego podlega ochronie konserwatorskiej. Wyznaczone na załączniku graficznym w skali 1 : 10000 granice obszaru wpisanego do rejestru zabytków nie pokrywają się z granicami obszaru chronionego decyzją z 1966 r. Mimo złej jakość technicznej ww. załącznika widać to wyraźnie. Nie potrzeba szczegółowych badań, polegających na nakładaniu na siebie załączników omawianych decyzji, przy pomocy graficznych programów komputerowych. Trudno twierdzić, że decyzją z 1983 r. jedynie wznowiono decyzję z dnia 13 sierpnia 1966 r.

Decyzja z 1983 r., podobnie jak decyzja z 1966 r., nie ustala w sposób jednoznaczny:

1. obszaru podlegającego ochronie;

2. obiektów podlegających ochronie;

3. na czym ma polegać ochrona.

Prócz wątpliwości natury merytorycznej nasuwają się wątpliwości natury prawnej. W momencie wejścia w życie obecnie obowiązującej ustawy o ochronie zabytków i opiece nad zabytkami utraciła „moc ustawa z dnia 15 lutego 1962 r. o ochronie dóbr kultury (Dz.U. z 1999 r. poz. 1150, z późn. zm.)" [art. 150 uoz].

Ustawa o ochronie zabytków i opiece nad zabytkami stanowi, że decyzje ostateczne „wydane na podstawie przepisów ustawy z dnia 15 lutego 1962 r. o ochronie dóbr kultury (Dz.U. z 1999 r. poz. 1150, z późn. zm.) zachowują ważność" [art. 140 ust. 1 uoz].

Decyzja z 1983 r. została wydana na podstawie art. 4 i art. 14 ust. 1 ustawy z dnia 15 lutego 1962 r. o ochronie dóbr kultury i o muzeach (Dz.U. nr 10, poz. 48). Ustawa o ochronie dóbr kultury i o muzeach zmieniła nazwę na "ustawa o ochronie dóbr kultury”, na podstawie ustawy o muzeach, w wersji uchwalonej w dniu 21 listopada 1996 r. (Dz.U. z 1997 nr 5, poz. 24). W ustawie z dnia 15 lutego 1962 r. o ochronie dóbr kultury i o muzeach (Dz.U. nr 10, poz. 48, z 1983 r. nr 38, poz. 173, z 1989 r. nr 35, poz. 192 oraz z 1990 r. nr 34, poz. 198 i nr 56, poz. 322 oraz z 1996 r. nr 106, poz. 496) wprowadzono następujące zmiany - w tytule ustawy skreślono wyrazy „i o muzeach” [art. 35 pkt 1 ustawy o muzeach].

Przepis art. 140 ust. 1 ustawy o ochronie zabytków i opiece nad zabytkami nie odnosi się do ustawy o ochronie dóbr kultury i o muzeach, ale do ustawy o ochronie dóbr kultury w wersji z 1999 r. Można z tego wyciągnąć wniosek, że decyzje wydane przed tą datą nie zachowują ważności, co oznaczałoby, że obydwie decyzje: z 1966 r. i z 1983 r. w sprawie wpisania Kazimierza Dolnego do rejestru zabytków przestały obowiązywać z mocy prawa. 


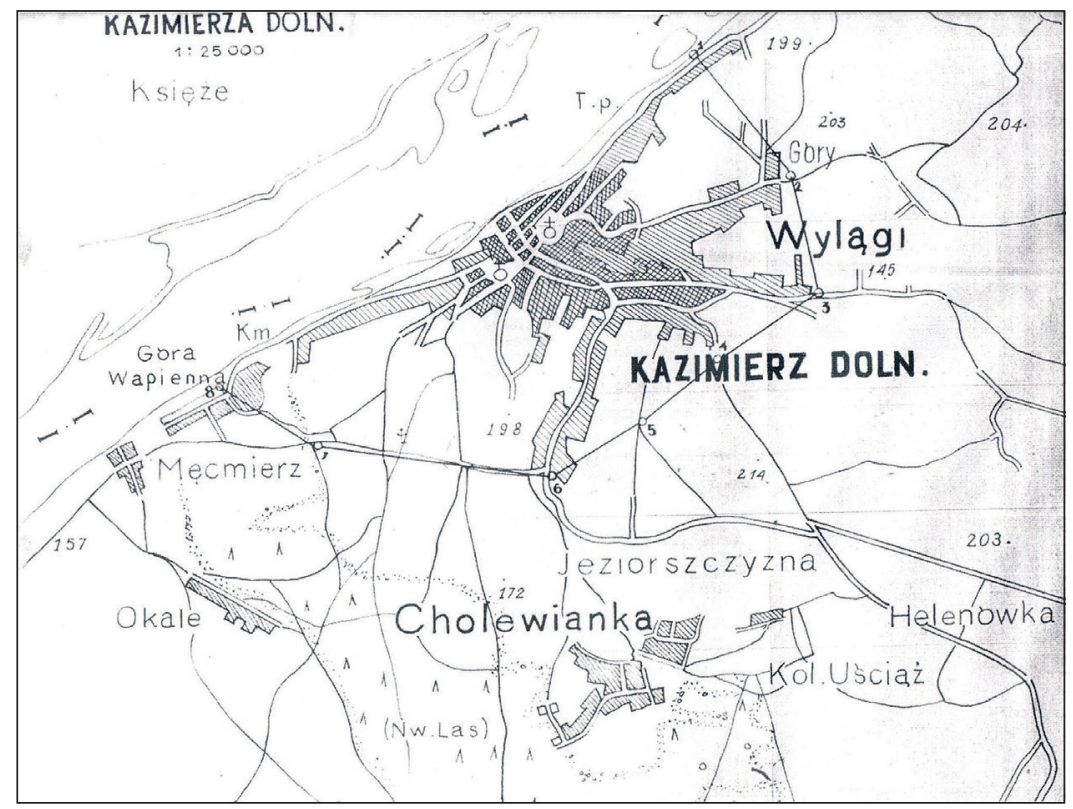

Ryc. 2. Załącznik do decyzji z 13 sierpnia 1966 r. w sprawie wpisania dobra kultury do rejestru zabytków

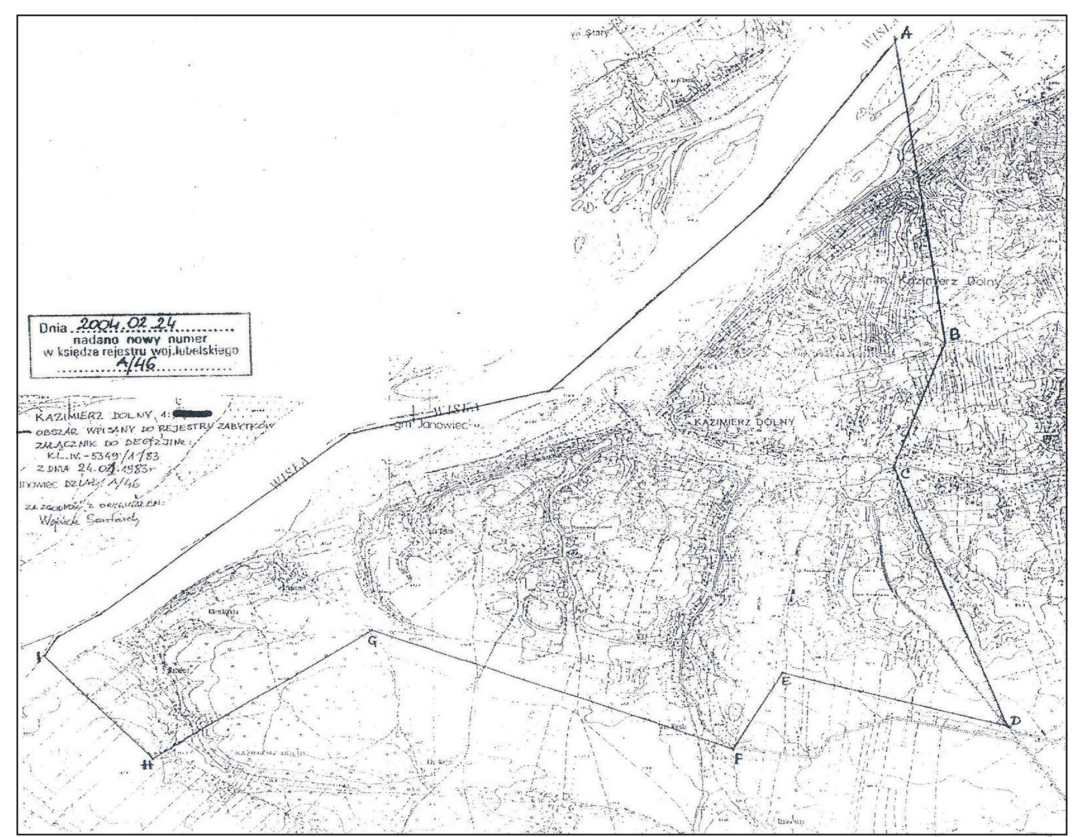

Ryc. 3. Załącznik do decyzji z 24 stycznia 1983 r. w sprawie wznowienia wpisu dobra kultury do rejestru zabytków 


\section{Pomnik historii - Zarządzenie Prezydenta RP z dnia 8 września 1994 r.}

Cytowane w całości Zarządzenie Prezydenta w sprawie uznania za pomnik historii Kazimierza Dolnego budzi szereg wątpliwości natury merytorycznej. Nie definiuje takich pojęć jak: zabudowa mieszkalna, pełen program budowli monumentalnych z okresu staropolskiego. Nie określa, które elementy układu urbanistycznego należy chronić - czy np. wszystkie drogi i ścieżki, które istniały w 1994 r., a może tylko te najstarsze.

Granica terenu uznanego za pomnik historii, narysowana na załączniku graficznym w skali 1: 20 000, ma około 3 mm grubości, co w terenie oznacza około 60 m szerokości. Żeby uświadomić sobie, ile to jest $60 \mathrm{~m}$, wystarczy powiedzieć, że w pasie $60 \mathrm{~m}$ można wybudować dwa rzędy domów jednorodzinnych. Co więcej, granicę wyznaczono na podstawie miejscowego planu ogólnego zagospodarowania przestrzennego, uchwalonego w dniu 28 lutego 1989 r., który od dawna nie obowiązuje. Z powyższego wynika, że nie wiadomo, jaki obszar podlega ochronie, które obiekty należy chronić i na czym ma polegać ochrona.

Wątpliwości natury prawnej jest jeszcze więcej. Obecnie obowiązująca ustawa o ochronie zabytków i opiece nad zabytkami stanowi, że:

1. dobra kultury wpisane do rejestru na podstawie ustawy z dnia 15 lutego 1962 r. o ochronie dóbr kultury (Dz.U. z 1999 r. poz. 1150, z późn. zm.) „stają się zabytkami wpisanymi do rejestru w rozumieniu niniejszej ustawy" [art. 142 ust. 1 uoz];

2. zabytki nieruchome „uznane za pomniki historii na podstawie dotychczasowych przepisów stają się pomnikami historii w rozumieniu niniejszej ustawy" [art. 142 ust. 2 uoz].

Zarządzenie Prezydenta w sprawie uznania za pomnik historii Kazimierza Dolnego wydano w 1994 r., na podstawie art. 6 ust. 1 ustawy z dnia 15 lutego 1962 r. o ochronie dóbr kultury i o muzeach (Dz.U. nr 10, poz. 48, z 1983 r. nr 38, poz. 173, z 1989 r. nr 35, poz. 192 oraz z 1990 r. nr 34, poz. 198 i nr 56, poz. 322).

Wydaje się, że przepis art. 142 ust. 2 ustawy o ochronie zabytków i opiece nad zabytkami: 1. pod pojęciem dotychczasowe przepisy rozumie ustawę o ochronie dóbr kultury, w brzmieniu opublikowanym w Dz.U. z 1999 r. poz. 1150 oraz jej późniejsze zmiany ustawa obowiązywała do 16.11.2003 r.

2. nie odnosi się do ustawy o ochronie dóbr kultury i o muzeach.

Jeśli przyjąć, że decyzje o wpisaniu do rejestru zabytków wygasły z mocy prawa, to tereny nimi objęte nie są pomnikiem historii, bo taki status mógł i może uzyskać jedynie obiekt wpisany do rejestru zabytków. Ponadto zarządzenia nie są źródłami prawa w rozumieniu przepisów art. 87 ust. 1 i ust. 2 Konstytucji Rzeczypospolitej Polskiej z 1997 r. Z powyższego wynika, że Kazimierz Dolny utracił status pomnika historii. 


\section{Pomniki historii według Narodowego Instytutu Dziedzictwa}

Narodowy Instytut Dziedzictwa (NID) to szacowna i kompetentna instytucja, która od lat zajmuje się zabytkami. „NID jest prawnym następcą Ośrodka Dokumentacji Zabytków, utworzonego w 1962." [si.NID]. Obecnie podległa Ministerstwu Kultury i Dziedzictwa Narodowego. „Misją NID jest tworzenie podstaw dla zrównoważonej ochrony dziedzictwa poprzez gromadzenie i upowszechnianie wiedzy o zabytkach, wyznaczanie standardów ich ochrony i konserwacji oraz kształtowanie świadomości społecznej w celu zachowania dziedzictwa kulturowego Polski dla przyszłych pokoleń." [si.NID].

Na stronie internetowej Narodowego Instytutu Dziedzictwa umieszczono wykaz pomników historii o nazwie „Lista obiektów uznanych przez Prezydenta RP za Pomniki Historii uporządkowana alfabetycznie [załącznik 2]. Na liście widnieje 108 pozycji, które można podzielić na szereg grup tematycznych, takich jak:

1. obiekty i zespoły sakralne;

2. zespoły parkowo-pałacowe;

3. obiekty obronne: zamki, twierdze;

4. obiekty techniki: kopalnie, kanały, fabryki oraz związane z nimi osiedla dla robotników;

5. obiekty szczególnie cenne ze względu na krajobraz;

6. pola bitew i inne miejsca, w których toczyły się wydarzenia kluczowe dla historii Polski;

7. obiekty archeologiczne;

8. części miast, gdzie zachował się historyczny układ urbanistyczny oraz cenne zespoły obiektów budowlanych.

Do tej ostatniej z wymienionych grup można zaliczyć:

1. Chełmno - stare miasto;

2. Gdańsk - miasto w zasięgu obwarowań z XVII w.;

3. Gdynia - historyczny układ urbanistyczny śródmieścia;

4. Kazimierz Dolny;

5. Kraków - historyczny zespół miasta;

6. Lublin - historyczny zespół architektoniczno-urbanistyczny;

7. Paczków - zespół staromiejski ze średniowiecznym systemem fortyfikacji;

8. Poznań - historyczny zespół miasta;

9. Przemyśl - zespół staromiejski;

10. Sandomierz - historyczny zespół architektoniczno-krajobrazowy;

11. Stary Sącz - zespół staromiejski wraz z klasztorem Sióstr Klarysek;

12. Torun - Stare i Nowe Miasto;

13. Warszawa - historyczny zespół miasta z Traktem Królewskim i Wilanowem;

14. Wrocław - zespół historycznego centrum;

15. Zamość - historyczny zespół miasta w zasięgu obwarowań XIX w.

Według Narodowego Instytutu Dziedzictwa:

1. zarządzeniami Prezydenta Rzeczypospolitej Polskiej z dnia 8 września 1994 r. zostało uznanych za pomniki historii 15 obiektów; 
2. rozporządzeniami Prezydenta Rzeczypospolitej Polskiej wydanymi w latach od 2000 do 2020 zostały uznane za pomniki historii 93 obiekty [si.NID.PH] oraz [si.NID.PH.Lm].

Zarządzeniami Prezydenta Rzeczypospolitej Polskiej status pomnika historii uzyskały (nazwy jak na si.NID.PH):

1. Biskupin - rezerwat archeologiczny;

2. Częstochowa - Jasna Góra, zespół klasztoru oo. Paulinów;

3. Frombork - zespół katedralny;

4. Gdańsk - miasto w zasięgu obwarowań z XVII w.;

5. Gniezno - katedra pw. Wniebowzięcia NMP i św. Wojciecha;

6. Kazimierz Dolny;

7. Kraków - historyczny zespół miasta;

8. Krzemionki k. Ostrowca Świętokrzyskiego - kopalnie krzemienia z okresu neolitu;

9. Malbork - zespół zamku krzyżackiego;

10. Ostrów Lednicki;

11. Toruń - Stare i Nowe Miasto;

12. Warszawa - historyczny zespół miasta z Traktem Królewskim i Wilanowem;

13. Wieliczka - kopalnia soli;

14. Wrocław - zespół historycznego centrum;

15. Zamość - historyczny zespół miasta w zasięgu obwarowań XIX w.

\section{Komentarz}

Nie wiadomo jak traktować ww. wykaz pomników historii o nazwie: „Lista obiektów uznanych przez Prezydenta RP za Pomniki Historii uporządkowana alfabetycznie"[si.NID.PH]:

1. czy Narodowy Instytutu Dziedzictwa wszystkie 108 obiektów traktuje jako pomniki historii?

2. czy jest to tylko lista obiektów, które mają lub miały status pomnika historii?

Jednoznaczne informacje dotyczące pomników historii można znaleźć w Systemie Informacji Prawnej Legalis - aktualizowanym na bieżąco, płatnym programie komputerowym (licencję sprzedaje Wydawnictwo C.H.Beck Sp. z o.o.). Legalis zawiera wykaz aktów prawa:

1. które obowiązuja, ich treść oraz daty od kiedy obowiązują i kolejne nowelizacje;

2. które przestały obowiązywać, ich treść oraz informacje w jakim okresie obowiązywały. W Systemie Informacji Prawnej Legalis:

1. wszystkie 15 zarządzeń ustanawiających pomniki historii opatrzono adnotacją - wersja nieobowiązująca [załącznik 3];

2. nie znaleziono rozporządzeń Prezydenta PR, które nadają status pomnika historii obiektom wymienionym $\mathrm{w}$ ww. zarządzeniach.

Prawdziwość informacji zawartych w Systemie Legalis, potwierdza fakt, że zarządzenia nie są źródłami prawa w rozumieniu przepisów art. 87 ust. 1 i ust. 2 Konstytucji Rzeczypo- 
spolitej Polskiej z 1997 r. Przyjmując, że Kazimierz Dolny utracił status pomnika historii, to w analogicznej sytuacji prawnej jest 14 wymienionych powyżej obiektów, które uznano za pomniki historii zarządzeniami Prezydenta RP, wydanymi 8 września 1994 r.

Artykuł dotyczy Kazimierza Dolnego, ale należy go traktować również jako apel o likwidację chaosu prawnego dotyczącego zabytków. Ma to szczególnie znaczenie dla umieszczonych na liście Narodowego Instytutu Dziedzictwa, a ustanowionych zarządzeniami pomników historii, będących częściami miast. Prócz Kazimierza Dolnego, to Gdańsk, Kraków, Toruń, Warszawa, Wrocław i Zamość.

Ludzie musza wiedzieć, czy żyją na terenie pomnika historii (a tym samym na terenie wpisanym do rejestru zabytków), czy nie. Przykładowo, wszystkie roboty budowlane (w rozumieniu ustawy Prawo budowlane), nawet te najdrobniejsze typu remont budynku jednorodzinnego (malowanie ścian, docieplenie, naprawa rynien itp.) wykonywane:

1. przy obiekcie budowlanym wpisanym do rejestru zabytków - wymagają pozwolenia na budowę;

2. na obszarze wpisanym do rejestru zabytków - wymagają zgłoszenia.

Do wniosku o pozwolenie na budowę oraz do zgłoszenia należy dołączyć pozwolenie wojewódzkiego konserwatora zabytków [art. 29 ust. 4 uPb].

Wykonanie ww. robót budowlanych bez pozwolenia konserwatora zabytków:

1. podlega karze w wysokości od 500 zł do 500000 zł [art. 107 ust. 1 i ust 2 uoz];

2. może zostać uznane za niszczenie zabytku, co jest karane pozbawieniem wolności do lat 8 [art. 108 ust. 1 uoz].

Skoro ustawodawca wprowadza tak drakońskie kary, to powinien w sposób jednoznaczny, niebudzący wątpliwości określić, co należy chronić i dlaczego.

Przyjmując, że wszystkie ustanowione w 1994 r. pomniki historii są nadal cenne dla naszej kultury, należy wydać dla ww. obiektów stosowne rozporządzenia. Nie wolno jednak zrobić tego przepisując treść ww. zarządzeń i kopiując załączniki graficzne. Wydanie rozporządzeń powinny poprzedzić badania, jednoznacznie wskazujące obszar podlegający ochronie i zasady ochrony.

Przy porządkowaniu stanu prawnego pomników historii warto również przeanalizować obowiązujące rozporządzenia, zaczynając od tych, które dotyczą części miast, a tym samym mają wpływ na życie znacznej liczby osób, np: Chełma, Gdyni, Lublina, Paczkowa, Poznania, Przemyśla, Sandomierza i Starego Sącza.

Nie jest przedmiotem niniejszego artykułu szczegółowe badanie ustaleń merytorycznych ww. rozporządzeń, ale nawet pobieżna analiza ich treści nie pozostawia wątpliwości, zasady ochrony są zbyt ogólnikowe, a granice obszarów uznanych za pomniki historii wyznaczone mało precyzyjnie, chociaż tu jest postęp - Gdynia, Paczków, Poznań, Przemyśl, Sandomierz i Stary Sącz mają ustalone granice w odniesieniu do działek ewidencyjnych. 


\section{Czy Kazimierz Dolny powinien być pomnikiem historii?}

Jak już napisano, dla miasta Kazimierza Dolnego wydano decyzje z 13 sierpnia 1966 r., decyzję z 24 stycznia 1983 r. oraz zarządzenie Prezydenta RP z 8 września 1994 r. (wg obecnych przepisów dziś już nieobowiązujące).

Ponadto wydano szereg decyzji o wpisie do rejestru zabytków poszczególnych obiektów, takich jak: ruiny zamku, kamienice, kościół farny, klasztor oo. Reformatów, spichlerze, synagoga. Dodatkowo całe miasto leży w Kazimierskim Parku Krajobrazowym - obszarze chronionym na mocy ustawy o ochronie przyrody.

Bez względu na to, czy przyjmuje się, że ww. decyzje i zarządzenie obowiązują czy nie, pozostaje bezspornym, że są wyjątkowo mało precyzyjne. Nadmiar form ochrony oraz brak jednoznacznie określonych zasad tej ochrony i granic obszaru podlegającego ochronie prowadzi do konfliktów między właścicielami nieruchomości a organami władzy oraz między samorządem a administracją rządową. Skutkuje to blokadą potrzebnych inwestycji. Przykładowo - uzgodnienia z wojewódzkim konserwatorem zabytków, niezbędne do uchwalenia miejscowych planów zagospodarowania przestrzennego trwają miesiącami [załącznik 1].

Trzeba pamiętać, że budynki i budowle Kazimierza Dolnego pochodzą z różnych epok i podlegały licznym przekształceniom. Miasto było zniszczone zarówno w czasie pierwszej, jak i drugiej wojny światowej. „W 1915 r. spłonęła północno-zachodnia pierzeja Rynku oraz cała ul. Senatorska. Kierując się troską o uratowanie walorów miasteczka, władze konserwatorskie sprzeciwiły się odbudowie spalonych budynków przed sporządzeniem planu zabudowania. Plan taki został wykonany w Ministerstwie Robót Publicznych w 1924 r.; zanim go ukończono część domów się zawaliło. Realizacja planu wymagała znacznych środków materialnych, których zabrakło. Kamienica Celejowska została odbudowana po nabyciu jej przez skarb państwa, kamienica Górskich - po wykupieniu przez grono miłośników Kazimierza, ale inne kamienice przy ul. Senatorskiej legły w gruzach, a spalone domy przy Rynku odbudowali, na ogół prymitywnie, ich właściciele." [Ostrowski 1980, s. 21-22] (ryc. 4 i 5).

Dom Pracy Twórczej Architekta SARP im. Stanisława Noakowskiego wybudowano „w latach 1954-55 według projektu Karola Sicińskiego na gruzach kilku istniejących tu wcześniej kamieniczek." [de Mezer-Sobotkowska, Sobotkowski 2012, s. 40], (ryc. 6).

Rozporządzenie w sprawie ustanowienia pomnika historii musi być poprzedzone wydaniem nowej decyzji o wpisie do rejestru zabytków. Należy zastanowić się, czy potrzebne są odrębne decyzje wpisujące do rejestru zabytków poszczególne budynki. Być może część z nich powinna zastać uchylona - im mniej dokumentów, tym więcej pewności, że ochrona będzie skuteczna. Projekty, zarówno nowej decyzji o wpisie do rejestru zabytków, jak i ww. rozporządzenia, muszą być poddane konsultacjom społecznym.

„Uznanie za pomnik historii to zaszczyt dla miasta i doskonała reklama. Jednak konieczne jest wydanie nowego rozporządzenia, które jednoznacznie określi granice pomnika historii oraz wskaże, co i jak należy w Kazimierzu chronić, tak by nie pozostawiać pola do jakiejkolwiek manipulacji. Wydanie rozporządzenia muszą poprzedzić konsultacje społeczne. Tylko traktowanie podmiotowe, a nie przedmiotowe mieszkańców, przyniesie wymierne skutki 
gwarantujące ochronę miasta. Mieszkańcy Kazimierza to nie barbarzyńcy - cechuje nas ogromne przywiązanie do naszej „małej ojczyzny”, szacunek dla historii i swoiste wyczucie piękna. Zdecydowana większość szpecących miasto obiektów to „dzieła” osób spoza miasteczka, dla których Kazimierz stanowi jedynie miejsce lokowania kapitału czy źródło dochodów.

Niewątpliwie istnieje coraz większa świadomość, iż powodzenie ekonomiczne mieszkańców utrzymujących się z turystyki, zależy od jakości krajobrazu, na który składają się zabytki i przyroda. Tam, gdzie w powszechnym odczuciu jest ładnie, rośnie wartość nieruchomości, przyjeżdżają turyści, a hotelarze, restauratorzy, handlarze zarabiają pieniądze."[załącznik 1].

Ochrona zabytków jest obowiązkiem zarówno władz, jak i społeczeństwa. Żeby była skuteczna, nie może być nacechowana uznaniowością. Tylko jednoznacznie, precyzyjne przepisy, ustalające obowiązki, zakazy i nakazy, znajdą akceptacje społeczna, a bez niej trudno coś chronić. Ponadto potrzebna jest szeroko rozumiana edukacja. Karami nie wymusi się wrażliwości na piękno i szacunku dla historii. Uznanie za pomnik historii powinno być traktowane jako zaszczyt przez mieszkańców terenu, który ten status uzyskał, a nie jako „dopust boży”.

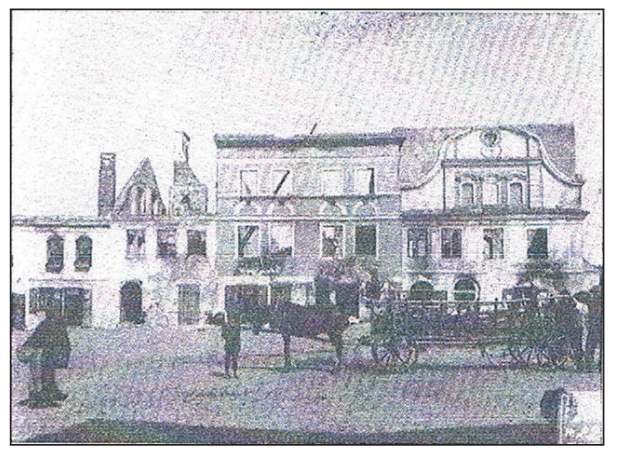

Ryc. 4. Kazimierz. Fragment Rynku w 1916 r. Fot. J. Kłos

Źródło: W. Ostrowski, 1980, s. 22

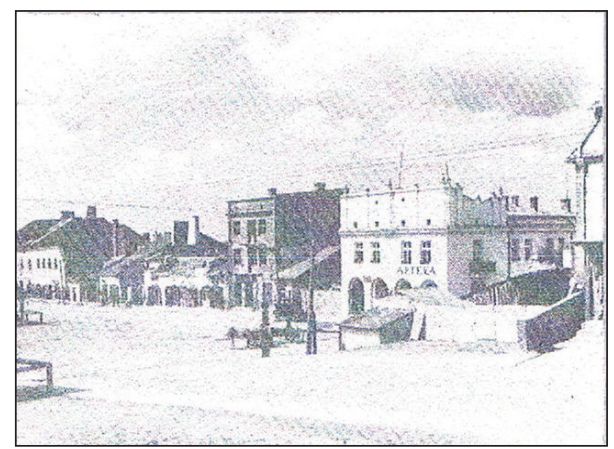

Ryc. 5. Kazimierz. Rynek w początku lat dwudziestych Insytytut Sztuki PAN Źródło:W. Ostrowski, 1980, s. 22 


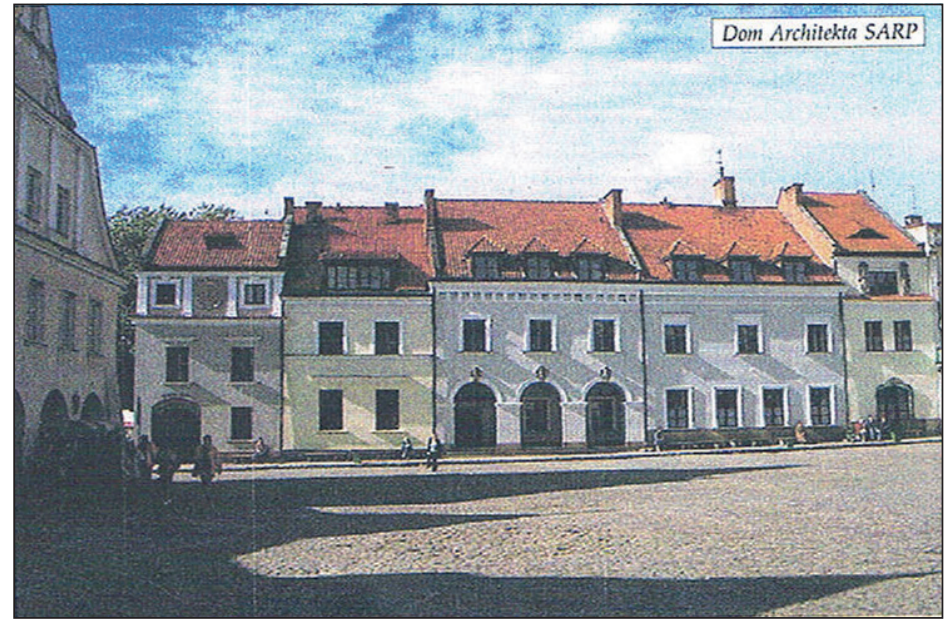

Ryc. 6. Dom Architekta SARP w Kazimierzu Dolnym

Źródło: K. de Mezer-Sobotkowska, Z. Sobotkowski, 2012, s. 40

\section{Literatura}

Adamczyk-Grabowska M. (wybór, opracowanie i przedmowa), 2010, Kazimierz vel Kuzmir. Miasteczko różowych snów, praca zbiorowa, Wydawnictwo Uniwersytetu Marii Curie-Skłodowskiej, Lublin.

de Mezer-Sobotkowska K., Sobotkowski Z., 2012, Kazimierz Dolny. Przewodnik turystyczny, Prywatna Agencja Geograficzna, Warszawa.

Ostrowski W., 1980, Zespoły zabytkowe a urbanistyka, Arkady, Warszawa.

Wawer K., 2020, Wyrok w sprawie PSEUDO-wpisu Kazimierza Dolnego do rejestru zabytków, artykuł umieszczony na stronie internetowej pt. „Z rynku” podtytuł „Strona internetowa Mieszkańców Kazimierza Dolnego" (http://z - rynku.pl 2020/03).

\section{Źródła prawa}

Konstytucja Rzeczypospolitej Polskiej z dnia 2 kwietnia 1997 r. (Dz.U. nr 78, poz. 483 z późn. zm.). 
Ustawy obowiązujące

Ustawa z dnia 7 lipca 1994 r. Prawo budowlane, tj. z dnia 21 maja 2019 r. (Dz.U. z 2019 r. poz. 1186, z późn. zm.), w skrócie uPb.

Ustawa z dnia 23 lipca 2003 r. o ochronie zabytków i opiece nad zabytkami, tj. z dnia 6 lutego 2020 r. (Dz.U. z 2020 r. poz. 282), w skrócie uoz.

Ustawy, które przestały obowiązywać

Ustawa z dnia 15 lutego 1962 r. o ochronie dóbr kultury i o muzeach (Dz.U. z 1962 r. nr 10, poz. 48).

Ustawa z dnia 15 lutego 1962 r. o ochronie dóbr kultury, tj. z dnia 10 grudnia 1999 r. (Dz.U. nr 98, poz. 1150).

Ustawa z dnia 21 listopada 1996 r. o muzeach (Dz.U. z 1997 r. nr 5, poz. 24).

\section{Rozporządzenia}

Rozporządzenie Prezydenta Rzeczypospolitej Polskiej z 13 kwietnia 2005 r. w sprawie uznania za pomnik historii (Dz.U. nr 64 z 2005 r. poz. 567 i 568) - dotyczy Chełmna-Stare Miasto. Rozporządzenie Prezydenta Rzeczypospolitej Polskiej z 25 kwietnia r. w sprawie uznania za pomnik historii „Lublin - historyczny zespół architektoniczno-urbanistyczny” (Dz.U. z 2007 r. nr 86, poz. 574).

Rozporządzenie Prezydenta Rzeczypospolitej Polskiej z 28 listopada 2008 r. w sprawie uznania za pomnik historii „Poznań - historyczny zespół miasta” (Dz.U. z 2008 r. nr 219, poz. 1401).

Rozporządzenie Prezydenta Rzeczypospolitej Polskiej z 22 października 2012 r. w sprawie uznania za pomnik historii „Paczków - zespół staromiejski ze średniowiecznym systemem fortyfikacji” (Dz.U. z 2012 r. poz. 1240).

Rozporządzenie Prezydenta Rzeczypospolitej Polskiej z 23 lutego 2015 r. w sprawie uznania za pomnik historii „Gdynia - historyczny układ urbanistyczny śródmieścia” (Dz.U. z 2015 r. poz. 356).

Rozporządzenie Prezydenta Rzeczypospolitej Polskiej z 22 listopada 2017 r. w sprawie uznania za pomnik historii "Sandomierz - historyczny zespół architektoniczno-krajobrazowy” (Dz.U. z 2017 r. poz. 2273).

Rozporządzenie Prezydenta Rzeczypospolitej Polskiej z 10 grudnia 2018 r. w sprawie uznania za pomnik historii „Stary Sącz - zespół staromiejski wraz z klasztorem Sióstr Klarysek” (Dz.U. z 2018 r. poz. 2415). 
Rozporządzenie Prezydenta Rzeczypospolitej Polskiej 10 grudnia 2018 r. w sprawie uznania za pomnik historii „Przemyśl - zespół staromiejski” (Dz.U. z 2018 r. poz. 2419).

\section{Strony internetowe}

www.kazimierz-dolny./pl Kazimierz Dolny - Oficjalna Strona Miasta Kazimierz Dolny, w skrócie si.OSMKD, w tym: zakładka MIASTO www. kazimierz-dolny./pl/miasto/pomnik-historii.

„Z rynku” podtytuł „Strona internetowa Mieszkańców Kazimierza Dolnego” (http://z - rynku.pl 2020/03).

https://pl.wikipedia.org/wiki/Narodowy_Instytut_Dziedzictwa, w skrócie si.NID dane $\mathrm{z}$ dnia 11.08.2020 r.

https://www.nid.pl/pl/Informacje ogólne/Zabytki w Polsce/Pomniki historii, w skrócie si.NID.PH, dane z dnia 11.08.2020 r.

https://www.nid.pl/pl/Informacje ogólne/Zabytki w Polsce/Pomniki historii/Lista miejsc, w skrócie si.NID. PH.Lm, dane z dnia 11.08.2020 r.

https://bdl.stat.gov.pl/BDL/dane/teryt/tabela\# , w skrócie si. GUS, dane z grudnia 2019 r.

System Informacji Prawnej Legalis, Wydawnictwo C.H.Beck Sp. z o.o. ul. Bonifraterska 17, 00-203 Warszawa.

\section{Dokumenty}

Decyzja z 13 sierpnia 1966 r. w sprawie wpisu dobra kultury do rejestru zabytków, nr KZ.V7/55/66, nr rejestru Dział A/46.

Decyzja z 24 stycznia 1983 r. w sprawie wznowienia wpisu dobra kultury do rejestru zabytków, nr KL.IV-5349/1/83, dział A/46. 


\section{Załącznik 1}

Wywiad z Panem Januszem Kowalskim, radnym miasta i gminy Kazimierz Dolny, przeprowadzony przez dr Annę Wieczorek, za pomocą poczty elektronicznej w dniu 16.03.2020 r., na potrzeby artykułu „Czy Kazimierz Dolny jest pomnikiem historii?”

\section{Od jak dawna mieszka Pan w Kazimierzu Dolnym?}

W Kazimierzu mieszkam od urodzenia.

\section{Od jak dawna jest Pan radnym miasta i gminy Kazimierz Dolny?}

Radnym byłem w latach 2010-2014 r. Obecnie funkcję radnego pełnię od 2018 r. (druga kadencja). W latach 2015-2019 byłem członkiem samorządu mieszkańców Kazimierza Dolnego. W latach 2009-2019 pełniłem również funkcję prezesa Stowarzyszenia Kupców i Przedsiębiorców w Kazimierzu Dolnym. Sprawy miasta niezależnie od pełnionych funkcji leżały mi zawsze na sercu i są mi bliskie. Moja rodzina z Kazimierzem związana jest od setek lat.

\section{Czy Kazimierz Dolny powinien mieć status pomnika historii?}

Kazimierz Dolny umiera. Sezon trwa tu dwa wakacyjne miesiące oraz po kilka dni w okresie świąteczno-noworocznym i w długi weekend majowy. Jeśli miasto nie wymyśli sposobu na przyciągnięcie turystów, to większość pensjonatów, restauracji i galerii zbankrutuje. Zdajemy sobie sprawę, że nie ma jednej, prostej recepty na zwiększenie ruchu turystycznego, ale doskonale wiemy, co przeszkadza w tworzeniu nowej, interesującej oferty. To między innymi regulacje dotyczące ochrony zabytków.

Decyzje o wpisaniu do rejestru zabytków z 1966 r. i z 1983 r. oraz Zarządzenie Prezydenta RP z 1994 r. w sprawie pomnika historii są ze sobą sprzeczne, nie wiadomo jak je stosować w praktyce. Granice obszarów chronionych nie dość, że różnią się od siebie, to w Zarządzeniu Prezydenta mają grubość około $3 \mathrm{~mm}$, co w terenie oznacza $60 \mathrm{~m}$. W pasie $60 \mathrm{~m}$ można wybudować dwa rzędy domków jednorodzinnych.

Budowa domu, a nawet najdrobniejszy remont wymaga zgody wojewódzkiego konserwatora zabytków. Na zgody czeka się miesiącami, czasem latami, co więcej cechuje je brak konsekwencji i uznaniowość. Jednym zabrania się budowy domku jednorodzinnego, a inni stawiają budynki wysokości $20 \mathrm{~m}$. Nie wiadomo, czy lepiej bez zgody naprawić urwaną rynnę albo wstawić uszkodzone dachówki i zapłacić karę, czy czekać na zgodę konserwatora i mieć zalany dom. To prowadzi do konfliktów mieszkańców z władzami.

Procedury sporządzania miejscowych planów zagospodarowania przestrzennego trwają latami, bo uzgodnienia z wojewódzkim konserwatorem zabytków trwają miesiącami. W świetle ustawy o planowaniu i zagospodarowaniu przestrzennym można je przeprowadzić w dwa tygodnie. Przykładowo, obecnie procedowany projekt miejscowego planu zagospodarowania przestrzennego dla części gminy Kazimierz Dolny, w obrębach: Kazimierz Dolny, Mięćmierz-Okale, Cholewianka, był czterokrotnie wysyłany do konserwatora zabytków, który trzykrotnie odmówił uzgodnienia, uzgodnił dopiero za czwartym razem. Wszystko to trwało od grudnia 2018 r. do lipca 2019 r. 
Jestem gorącym zwolennikiem ochrony wszystkiego tego, co cenne w Kazimierzu Dolnym. Uznanie za pomnik historii to zaszczyt dla miasta i doskonała reklama. Dlatego uważam, że powinno zostać wydanie nowe rozporządzenie Prezydenta RP w sprawie uznania za pomnik historii, z jednoznacznie ustalonym przedmiotem i zasadami ochrony. Wydanie rozporządzenia muszą poprzedzić konsultacje społeczne. Tylko traktowanie podmiotowe, a nie przedmiotowe mieszkańców, przynosi skutki we wprowadzaniu regulacji chroniących zabytki i przyrodę. Nasi mieszkańcy to nie barbarzyńcy - cechuje ich ogromne przywiązanie do naszej „małej ojczyzny”, szacunek dla historii i wyczucie piękna.

Ponadto istnieje coraz większa świadomość, iż powodzenie ekonomiczne zależy od jakości krajobrazu, na który składają się zabytki i przyroda. Tam, gdzie w powszechnym odczuciu jest ładnie i jest co zwiedzać, rośnie wartość nieruchomości, przyjeżdżają turyści, a hotelarze i restauratorzy zarabiają pieniądze.

\section{Załącznik 2}

Lista obiektów uznanych przez Prezydenta RP za Pomniki Historii według Narodowego Instytutu Dziedzictwa uporządkowana alfabetycznie:

1. Białystok - zespół kościoła pw. Chrystusa Króla i św. Rocha

2. Biskupin - rezerwat archeologiczny

3. Bochnia - kopalnia soli

4. Bohoniki i Kruszyniany - meczety i mizary

5. Bóbrka - najstarsza kopalnia ropy naftowej

6. Brzeg - Zamek Piastów Śląskich z renesansową bramą i kaplicą zamkową pod wezwaniem św. Jadwigi - nekropolią Piastów

7. Chełmno - stare miasto

8. Ciechocinek - Zespół tężni i warzelni soli wraz z parkami Tężniowym i Zdrojowym

9. Częstochowa - Jasna Góra, zespół klasztoru oo. Paulinów

10. Dobrzyca - zespół pałacowo-parkowy

11. Duszniki Zdrój- młyn papierniczy

12. Frombork - zespół katedralny

13. Gdańsk - miasto w zasięgu obwarowań z XVII w.

14. Gdańsk - pole bitwy na Westerplatte

15. Gdańsk - Stocznia Gdańska, miejsce narodzin Solidarności

16. Gdańsk - Twierdza Wisłoujście

17. Gdańsk - Zespół pocystersko-katedralny w Gdańsku Oliwie

18. Gdynia - historyczny układ urbanistyczny śródmieścia

19. Gliwice - radiostacja

20. Gniezno - katedra pw. Wniebowzięcia NMP i św. Wojciecha

21. Gostyń-Głogówko - zespół klasztorny Kongregacji Oratorium św. Filipa Neri

22. Gościkowo-Paradyż - Pocysterski zespół klasztorny 
23. Góra Św. Anny - komponowany krajobraz kulturowo-przyrodniczy

24. Grudziądz - Zespół zabytkowych spichlerzy wraz z panoramą od strony Wisły

25. Grunwald - Pole Bitwy

26. Janów Podlaski - Stadnina koni

27. Jawor - kościół ewangelicko-augsburski pw. Ducha Świętego zwany kościołem Pokoju

28. Kalwaria Zebrzydowska - krajobrazowy zespół manierystycznego parku pielgrzymkowego

29. Kamień Pomorski - zespół katedralny

30. Kanał Augustowski - droga wodna

31. Kanał Elbląski

32. Katowice - Gmach Województwa i Sejmu Śląskiego oraz zespół katedralny

33. Katowice - osiedle robotnicze Nikiszowiec

34. Kazimierz Dolny

35. Kielce - dawny pałac biskupów i katedra

36. Klępsk - kościół pw. Nawiedzenia Najświętszej Maryi Panny

37. Kołbacz - założenie dawnego klasztoru cystersów

38. Koszuty - zespół dworsko-parkowy

39. Kotlina Jeleniogórska - pałace i parki krajobrazowe Kotliny Jeleniogórskiej

40. Kozłówka - zespół pałacowo-parkowy

41. Kórnik - zespół zamkowo-parkowy wraz z kościołem parafialnym - nekropolią właścicieli

42. Kraków - historyczny zespół miasta

43. Kraków - Kopiec Kościuszki z otoczeniem

44. Krasiczyn - zespół zamkowo-parkowy

45. Krzemionki k. Ostrowca Świętokrzyskiego - kopalnie krzemienia z okresu neolitu

46. Krzeszów - zespół dawnego opactwa cystersów

47. Kwidzyn - zespół katedralno-zamkowy

48. Ląd - zespół dawnego opactwa cysterskiego w Lądzie nad Wartą

49. Legnickie Pole - pobenedyktyński zespół klasztorny

50. Leżajsk - zespół klasztorny oo. Bernardynów

51. Lidzbark Warmiński - zamek biskupów warmińskich

52. Lubiń - zespół opactwa benedyktynów

53. Lublin - historyczny zespół architektoniczno-urbanistyczny

54. Łańcut - zespół zamkowo-parkowy

55. Łęknica - Park Mużakowski, park w stylu krajobrazowym

56. Łódź - wielokulturowy krajobraz miasta przemysłowego

57. Łowicz - Bazylika Katedralna (dawna Kolegiata Prymasowska) pod wezwaniem Wniebowzięcia Najświętszej Marii Panny

58. Malbork - zespół zamku krzyżackiego

59. Nieborów i Arkadia - Zespół pałacowo ogrodowy i ogród sentymentalno-romantyczny

60. Nowy Wiśnicz - zespół architektoniczno-krajobrazowy

61. Nysa - zespół kościoła farnego pod wezwaniem św. Jakuba Starszego Apostoła i św. Agnieszki Dziewicy i Męczennicy 
62. Oblęgorek - pałacyk Henryka Sienkiewicza wraz z zabytkowym parkiem i aleją lipową

63. Olesno - kościół odpustowy pod wezwaniem św. Anny

64. Ostrów Lednicki

65. Ozimek - żelazny łańcuchowy most wiszący na rzece Mała Panew

66. Paczków - zespół staromiejski ze średniowiecznym systemem fortyfikacji

67. Pelplin - zespół pocystersko-katedralny

68. Płock - Wzgórze Tumskie

69. Poznań - historyczny zespół miasta

70. Przemyśl - Twierdza Przemyśl

71. Przemyśl - zespół staromiejski

72. Pułtusk - kolegiata pod wezwaniem Zwiastowania Najświętszej Maryi Panny

73. Racławice - teren historycznej Bitwy Racławickiej

74. Radruż - Zespół cerkiewny

75. Rogalin - zespół pałacowy z ogrodem i parkiem

76. Rydzyna - założenie rezydencjonalno-urbanistyczne

77. Rytwiany - pokamedulski zespół klasztorny Pustelnia Złotego Lasu

78. Sandomierz - historyczny zespół architektoniczno-krajobrazowy

79. Srebrna Góra - Twierdza Srebrnogórska, nowożytna warownia górska z XVIII w.

80. Staniątki - opactwo św. Wojciecha Mniszek Benedyktynek

81. Stargard - zespół kościoła pod wezwaniem Najświętszej Marii Panny Królowej Świata oraz średniowieczne mury obronne miasta

82. Stary Sącz - zespół staromiejski wraz z klasztorem Sióstr Klarysek

83. Strzegom - kościół pod wezwaniem św.św. Apostołów Piotra i Pawła

84. Strzelno - zespół dawnego klasztoru Norbertanek

85. Sulejów - zespół opactwa cystersów

86. Świdnica - katedra pw. św. Stanisława Biskupa Męczennika i św. Wacława Męczennika

87. Świdnica - zespół kościoła ewangelicko-augsburskiego pw. Świętej Trójcy

88. Święta Lipka - sanktuarium pielgrzymkowe

89. Święty Krzyż - pobenedyktyński zespół klasztorny oraz przedchrześcijańskie obwałowania kamienne na Łysej Górze

90. Szalowa - kościół parafialny św. Michała Archanioła

91. Tarnowskie Góry - podziemia zabytkowej kopalni rud srebronośnych oraz sztolni "Czarnego Pstraga"

92. Toruń - Stare i Nowe Miasto

93. Trzebnica - zespół dawnego opactwa cysterek

94. Tyniec - zespół opactwa benedyktynów

95. Ujazd - ruiny zamku Krzyżtopór

96. Wąchock - zespół opactwa cystersów

97. Warszawa - historyczny zespół miasta z Traktem Królewskim i Wilanowem

98. Warszawa - Zespół Stacji Filtrów Williama Lindleya

99. Warszawa - zespół zabytkowych cmentarzy wyznaniowych na Powązkach 
100. Wieliczka - kopalnia soli

101. Wiślica - zespół kolegiaty pod wezwaniem Narodzenia Najświętszej Maryi Panny wraz z reliktami kościoła pod wezwaniem św. Mikołaja oraz grodzisko

102. Włocławek - katedra pod wezwaniem Wniebowzięcia Najświętszej Maryi Panny

103. Wrocław - zespół historycznego centrum

104. Wrocław - Hala Stulecia

105. Zabrze - zespół zabytkowych kopalni węgla kamiennego

106. Zamość - historyczny zespół miasta w zasięgu obwarowań XIX w.

107. Żagań - poaugustiański zespół klasztorny

108. Żyrardów - XIX-wieczna Osada Fabryczna

\section{Załącznik 3}

Zarządzenia Prezydenta Rzeczypospolitej Polskiej w sprawie uznania za pomnik historii wykazane jako wersje nieobowiązujące w Systemie Informacji Prawnej Legalis, Wydawnictwo C.H.Beck Sp. z o.o. ul. Bonifraterska nr 17, 00-203 Warszawa (kolejność wg Legalis).

Zarządzenie Prezydenta Rzeczypospolitej Polskiej w sprawie uznania za pomnik historii z dnia 8 września 1994 r. (M.P. nr 50, poz. 412); dotyczy pomnika historii „rezerwat archeologiczny Biskupin", położony we wsi Biskupin w gminie Gąsawa w województwie bydgoskim.

Zarządzenie Prezydenta Rzeczypospolitej Polskiej w sprawie uznania za pomnik historii z dnia 8 września 1994 r. (M.P. nr 50, poz. 413); dotyczy pomnika historii „Częstochowa Jasna Góra - zespół klasztoru oo. Paulinów".

Zarządzenie Prezydenta Rzeczypospolitej Polskiej w sprawie uznania za pomnik historii z dnia 8 września 1994 r. (M.P. nr 50, poz. 414); dotyczy pomnika historii „Frombork - zespół katedralny", położony we Fromborku w województwie elbląskim.

Zarządzenie Prezydenta Rzeczypospolitej Polskiej w sprawie uznania za pomnik historii z dnia 8 września 1994 r. (M.P. nr 50, poz. 415); dotyczy pomnika historii „Gdańsk - miasto w zasięgu obwarowań XVII w."

Zarządzenie Prezydenta Rzeczypospolitej Polskiej w sprawie uznania za pomnik historii z dnia 8 września 1994 r. (M.P. nr 50, poz. 416); dotyczy pomnika historii „Gniezno - Katedrę p.w. Wniebowzięcia Najświętszej Marii Panny i św. Wojciecha”, położony w Gnieźnie w województwie poznańskim.

Zarządzenie Prezydenta Rzeczypospolitej Polskiej w sprawie uznania za pomnik historii z dnia 8 września 1994 r. (M.P. nr 50, poz. 417); dotyczy pomnika historii „Kazimierz Dolny”, położony w województwie lubelskim.

Zarządzenie Prezydenta Rzeczypospolitej Polskiej w sprawie uznania za pomnik historii z dnia 8 września 1994 r. (M.P. nr 50, poz. 418); dotyczy pomnika historii „Kraków - historyczny zespół miasta". 
Zarządzenie Prezydenta Rzeczypospolitej Polskiej w sprawie uznania za pomnik historii z dnia 8 września 1994 r. (M.P. nr 50, poz. 419); dotyczy pomnika historii „Krzemionki - kopalnie krzemienia z epoki neolitu", położone we wsi Sudół w gminie Bodzechów w województwie kieleckim.

Zarządzenie Prezydenta Rzeczypospolitej Polskiej w sprawie uznania za pomnik historii z dnia 8 września 1994 r. (M.P. nr 50, poz. 420); dotyczy pomnika historii „Malbork - zespół zamku krzyżackiego", położony w Malborku w województwie elbląskim.

Zarządzenie Prezydenta Rzeczypospolitej Polskiej w sprawie uznania za pomnik historii z dnia 8 września 1994 r. (M.P. nr 50, poz. 421); dotyczy pomnika historii „wyspa - Ostrów Lednicki”, położona na Jeziorze Lednickim we wsi Lednogóra w gminie Lubowo w województwie poznańskim.

Zarządzenie Prezydenta Rzeczypospolitej Polskiej w sprawie uznania za pomnik historii z dnia 8 września 1994 r. (M.P. nr 50, poz. 422); dotyczy pomnika historii „Toruń - Stare i Nowe Miasto".

Zarządzenie Prezydenta Rzeczypospolitej Polskiej w sprawie uznania za pomnik historii z dnia 8 września 1994 r. (M.P. nr 50, poz. 423); dotyczy pomnika historii „Warszawa - historyczny zespół miasta z traktem królewskim i Wilanowem".

Zarządzenie Prezydenta Rzeczypospolitej Polskiej w sprawie uznania za pomnik historii z dnia 8 września 1994 r. (M.P. nr 50, poz. 424); dotyczy pomnika historii „Wieliczka - kopalnia soli", położona pod miastem Wieliczka w województwie krakowskim.

Zarządzenie Prezydenta Rzeczypospolitej Polskiej w sprawie uznania za pomnik historii z dnia 8 września 1994 r. (M.P. nr 50, poz. 425); dotyczy pomnika historii „Wrocław - zespół historycznego centrum".

Zarządzenie Prezydenta Rzeczypospolitej Polskiej w sprawie uznania za pomnik historii z dnia 8 września 1994 r. (M.P. nr 50, poz. 426); dotyczy pomnika historii „Zamość - historyczny zespół miasta w zasięgu obwarowań XIX w." 


\title{
Is Kazimierz Dolny a monument of history?
}

\begin{abstract}
Undisputedly, Kazimierz Dolny is of special cultural significance for culture and thus meets the requirements to be considered as a monument of history. Unfortunately, the relevant regulations concerning the protection of historical monuments: the decisions of 1966 and 1983 on the inclusion of the town into the register of historical monuments and the ordinance of the President of the Republic of Poland of 1994 on recognizing Kazimierz Dolny as a monument of history raise a number of questions of a substantive and legal nature - it is uncertain whether they are valid. Such a situation causes conflicts between the inhabitants of Kazimierz Dolny and the authorities, especially the Regional Heritage Protection Authority.

In order to provide Kazimierz Dolny with appropriate legal protection, the above-mentioned decisions of 1966 and 1983, as well as the 1994 ordinance, should be removed from legal circulation. Next, an ordinance of the President of the Republic of Poland should be issued to recognise the city as a monument of history, clearly defining the object and principles of the protection. The regulation should be preceded by research that would clearly indicate the area to be protected and specify what should be protected there and why.

This paper should be treated as an appeal to eliminate the legal chaos concerning the monuments of history. There are several monuments in a similar situation as Kazimierz Dolny, which were recognised as monuments of history by the ordinances of President of Poland issued in 1994. The protection of monuments is the duty of both the authorities and the society. Only clearly and precisely defined obligations will be accepted by the society, without the cooperation of which it is difficult to protect anything.

Moreover, education in various forms is needed. Penalties cannot enforce appreciation of beauty and respect for history. The recognition of an area as a monument of history should be treated as an honour by the inhabitants of a particular area, and not as "divine retribution".
\end{abstract}

Key words: Kazimierz Dolny, monuments, register of monuments, monuments of history

\footnotetext{
Anna Wieczorek - na Politechnice Warszawskiej ukończyła Wydział Architektury, Podyplomowe Studium Urbanistyki, Studium Doskonalenia Pedagogicznego oraz uzyskała dyplom doktora nauk technicznych. Posiada uprawnienia do projektowania w planowaniu przestrzennym oraz uprawnienia do pełnienia samodzielnych funkcji technicznych w budownictwie. Specjalizuje się w wykonywaniu projektów miejscowych planów zagospodarowania przestrzennego (główny projektant ponad 30 uchwalonych projektów planów miejscowych) oraz projektów studiów uwarunkowań i kierunków zagospodarowania przestrzennego gmin (główny projektant 5 uchwalonych stdiów). Ma doświadczenie w pracy ze studentami - na Politechnice Warszawskiej i w Wyższej Szkole Przedsiębiorczości i Administracji w Lublinie. Należy do Mazowieckiej Okręgowej Izby Architektów z siedzibq w Warszawie oraz Pan-Europejskiej Federacji Ochrony Zabytków - Europa Nostra z siedzibq̨ w Holandii.

Anna Wieczorek - graduate of the Warsaw University of Technology - Faculty of Architecture, Postgraduate Town Planning Studies, Pedagogical study, PhD in technical science. Holds professional permits for spatial planning and is authorised to perform independent technical functions in construction. Specialises in the preparation of local spatial development plans (is the main designer of more than 30 approved local development plans) and of the studies of conditions and directions of the spatial development of municipalities (main designer of 5 approved studies). Has experience in working with students - at the Warsaw University of Technology and the University College of Enterprise and Administration in Lublin. Member of the Warsaw-based Masovian Chamber of Architects and the Pan-European Federation for Cultural Heritage, Europa Nostra based in the Netherlands.
} 